\title{
Papillitis in a Typhoid fever patient with toxic encephalopathy and septic shock: a rare complication?
}

Primal Sudjana, Hadi Jusuf

\begin{abstract}
Abstrak
Demam tifoid masih merupakan masalah umum dan masalah kesehatan utama di negara berkembang termasuk Indonesia. Komplikasi demam tifoid dapat mengenai berbagai organ seperti traktus gastrointestinal, hati, ginjal, susunan saraf pusat (SSP) dan lainnya. Komplikasi SSP di antaranya adalah ensefalopati toksik, meningitis dan ensefalitis. Satu kasus demam tifoid dengan komplikasi ensefalopati toksik, syok septik dan juga papilitis dilaporkan. Seorang wanita berusia 22 tahun dibawa ke RS karena panas, sakit kepala selama lebih dari 4 minggu dan 2 hari sebelum masuk kesadaran memburuk. Diagnosis demam tifoid ditegakkan setelah dikonfirmasikan dengan hasil positif Salmonella typhi pada kultur darah dan sumsum tulang. Pemeriksaan funduskopi memperlihatkan adanya edema papil bilateral dan didiagnosis sebagai suatu papillitis bilateral. Pasien diobati dengan antibiotik (kloramfenikol and sefalosporin), pemberian cairan, kortikosteroid dosis tinggi dan obat inotropik. Setelah 3 minggu perawatan, pasien pulang dengan perbaikan klinis dan 2 minggu kemudian papil kembali pada keadaan normal tanpa adanya ganguan penglihatan. Meskipun kami tidak mengkonfirmasi penyebab lain dari papillitis bilateral pada pasien ini, kami menyimpulkan bahwa papillitis tersebut merupakan suatu komplikasi dari demam tifoid.
\end{abstract}

\begin{abstract}
Abtract
Typhoid fever is still prevalent and a major public health problem in developing countries including Indonesia. Typhoid fever complications involve various organ such as gastrointestinal tract itself, liver, kidney, CNS and others. Amongs CNS complications are toxic encephalopathy, meningitis and encephalitis. One typhoid fever case with toxic encephalopathy and septic shock complication who also complained visual disturbance is reported. A 22 years old female admitted to the hospital due to fever, headache for more than 4 weeks and the consciousness deteriorated two days prior to admission. Typhoid fever was confirmed by both blood and bone marrow positive culture for Salmonella typhi. Funduscopy revealed bilateral papiledema and a bilateral papillitis was diagnosed. The patient was treated with antibiotic, hemostatic support, high dose corticosteroid and vasopressor. After 3 weeks of hospitalization the patient was discharged from the hospital with clinical improvement and 2 weeks afterward the papil were back to normal. Since we did not confirm other possible cause of bilateral papillitis in this patient, we conclude that papillitis is a complication of typhoid fever.
\end{abstract}

\section{INTRODUCTION}

In developing countries including Indonesia, typhoid fever remains as an important public health problem. The disease is endemic and new cases can be seen all year long. In Indonesia each year about 640,000 $1,500,000$ cases of typhoid fever are reported with mortality rate of $1.6-3 \% 1$. In West Java; where this case took place; in 1995, 25,877 typhoid fever cases were reported and 9,887 cases were hospitalized with CFR of $3.74 \%$ (West Java Health Profile, 1996).

Typhoid fever complication may involve both intestinal and extra intestinal. Among extra intestinal complications, acute confusional state is the most prevalent ${ }^{2}$.

Infectious Disease Unit, Dept of Internal Medicine, Faculty of Medicine, Padjadjaran University/ Hasan Sadikin General Hospital, Bandung, Indonesia.
We report a typhoid fever case with toxic encephalopathy complicated with septic shock and visual disturbance.

\section{CASE REPORT}

A 22 years old housewife was admitted to the Hasan Sadikin hospital with 6 weeks history of high fever, headache and nausea. Few days later she also experienced productive cough and then sought medication. The symptoms were gradually disappeared but remained subfebrile. Twelve days before admission the body temperature suddenly rose and ten days later she became delirious.

On admission (May 15, 1997) the patient was observed as severely ill with fever and delirium. The blood pressure was $105 / 60 \mathrm{mmHg}$, pulse rate $116 / \mathrm{min}$, respiratory rate $24 / \mathrm{min}$, and body temperature $38.1^{\circ} \mathrm{C}$. Neither splenomegali nor hepatomegali was detected. Pathological reflexes and neck rigidity were not found. Laboratory tests revealed a haemo- 
globin of $12.6 \mathrm{~g} / \mathrm{dl}$, white blood cell count was $5700 / \mathrm{mm}^{3}$, platelet $142,000 / \mathrm{mm}^{3}$. Ureum was 27.9 $\mathrm{g} / \mathrm{dl}$, creatinine $1.4 \mathrm{mg} / \mathrm{dl}$, random blood sugar was $127 \mathrm{mg} / \mathrm{dl}$. ECG showed sinus tachycardia and chest $\mathrm{X}$-ray was within normal limit. We suspected typhoid fever with toxic encephalopathy as a working diagnosis with tuberculosis meningitis as differential diagnosis. The Neurologist found bilateral papilledema with suspected pseudotumor or papillitis as a cause. Liquor cerebrospinalis was normal and also head CT scan. Intravenous chloramphenicol $500 \mathrm{mg} 4$ times a day was administered, dexamethasone $3 \mathrm{mg} / \mathrm{kg}$ body weight followed with $1 \mathrm{mg} / \mathrm{kg}$ body weight every 6 hours was also given. On May 17, 1997 the patient fell into septic shock and supportive treatments (dopamine etc.) were given. On May 19, 1997 the patients gained consciousness and became alert, haemodynamic was stable and ophthalmologist was consulted due to visual disturbance on day ten. The visus was $5 / 12$ in both eyes, and papillitis ODS was confirmed. Blood culture was positive for Salmonella typhi.

After 19 days of hospitalization the patient was discharged from hospital with normal both clinical and laboratory profile. On follow up 3 months later the visus was almost normal (VOD 6/7 and VOS 6/7).

\section{DISCUSSION}

Extra intestinal complication of typhoid fever have been reported with various organ involvement including neuropsychiatric, musculosceletal, haematological, renal, ovary, joint, bone, spine etc 2,3 . Acute confusional state is the most common neurological manifestation ${ }^{4,5}$.

In this case the length of fever prior to admission is quite unusual for typhoid fever, perhaps there was some recovery after receiving treatment but due to inadequacy of treatment it relapsed (12 days before admission). The patient was severely ill, delirious and although treatment was given still developed septic shock. Although multidrug - resistant Salmonella typhi have been widely reported6, in our hospital 94.4
$\%$ of $S$. typhi isolates are sensitive to chlorampheni$\mathrm{col}^{7}$ which is still a drug of choice for typhoid fever. Chloramphenicol $500 \mathrm{mg}$ was given intravenously 4 times a day combined with high dose dexamethasone as previously reported 8 .

After consciousness was gained, both neurological and ophthalmological examinations showed the evidence of bilateral papillitis. CT scan of the head showed no intracranial masses. On 3 months follow up the visual sight was almost normal.

According to our knowledge it has not been reported earlier a typhoid fever with toxic encephalopathy, septic shock and bilateral papillitis. Since we could not confirm any other possibilities which might have caused papillitis and it recovered with the improvement of the disease, we conclude that it was a complication of typhoid fever.

\section{REFERENCES}

1. Simanjuntak C. Epidemiology of typhoid fever in Indonesia, Proc. International Symposia on Tropical and Infectious Diseases Bandung-Indonesia; 1993.

2. Mandal BK. Salmonella infections, In: G.C. Cook editor, Manson's Tropical Diseases, $20^{\text {th }}$ ed, London: WB Saunders, 1996; 849-63.

3. Mandal BK. Salmonella infections. Medicine 1992; 5: 4393 7.

4. Khosla SN. Severe typhoid fever and appraisal of its profile In: R.H.H. Nelwan editor, Typhoid fever, Profile, Diagnosis and Treatment in the 1990's 1992; 753.

5. Ali G, Rashid S, Kamli MA, Shah PA, Allaqaband GQ. Spectrum of neuropsychiatric complications in 791 cases of typhoid fever. Trop Med Inter Health 1997; 2: 314-8.

6. Gupta A. Multidrug-resistant typhoid fever in children: epidemiology and therapeutic approach. Pediatr Infect Dis J 1994; 13: 134-40.

7. Sinaga H, Parwati I, Semaun E. Pola kepekaan Salmonella dari biakan gall terhadap antibiotika di RS Dr. Hasan Sadikin Bandung, Pekan Ilmiah FK Unpad 1996.

8. Hoffman SL, Punjabi NH, Kumala S. Reduction of mortality in chloramphenicol-treated severe typhoid fever by highdose dexamethasone. New Eng J Med 1984; 310; 82-8. 